logos_i_ethos_2021_(57), s. 25-60

DOI: http://dx.doi.org/10.15633/lie.4031

\title{
Zbyszek Dymarski
}

https://orcid.org/0000-0002-3637-2661

Uniwersytet Gdański

\section{O możliwym, lecz nie zaistniałym sporze - problem ludzkiej wolności w ujęciu Józefa Tischnera i Leszka Kołakowskiego'}

\section{Wprowadzenie}

Dla Józefa Tischnera nie tylko spotkanie $\mathrm{z}$ drugim było źródłem istotnych filozoficznych inspiracji. Ważnym sposobem dochodzenia do prawdy były dla niego też debaty. Traktował je nie tyle jako jeszcze jeden sposób głoszenia światu swoich przekonań (jak to często bywa w świecie polityki), ile jako wyzwanie do uporządkowania własnych poglądów oraz doprecyzowywanie ich w obliczu argumentów oponentów. Chciał, by i uczestnicy debat, i ci, co je śledzą, mogli poznać jego racje i stojące za nimi argumenty.

W zasadzie Tischner toczył dwie debaty. Jedną z tomizmem rozwijanym przez przedstawicieli tzw. szkoły lubelskiej. Prowadził ją przez całą dekadę lat 7o. głównie na łamach naukowych i opiniotwórczych pism
Zbyszek Dymarski, adiunkt w Instytucie Badań nad Kulturą Uniwersytetu Gdańskiego. Absolwent Politechniki Gdańskiej, Papieskiej Akademii Teologicznej w Krakowie oraz Wyższej Szkoły Komunikacji Społecznej w Gdyni. Prowadzi badania z dziedziny antropologii filozoficznej, antropologii religii i antropologii miasta. Kieruje Pracownią Filozofii i Antropologii Miasta Europejskiego. Prezes Pomorskiego Towarzystwa Filozoficzno-Teologicznego oraz zastępca redaktora naczelnego „Karto-Teki Gdańskiej”. Opublikował między innymi: Dwugtos o złu. Ze studiów nad myśla Józefa $i$ Tischnera i Leszka Kołakowskiego (Gdańsk 2009) oraz (red. nauk.) Człowiek i miasto. Gdańszczanie między stara a nową tożsamościa (Gdańsk 2017).

1 Badania wsparło Ministerstwo Nauki i Szkolnictwa Wyższego (Grant nr 11H 130471 82). 
wydawanych przez katolików świeckich, takich jak „Znak” i „Tygodnik Powszechny"2. Jej kres wiąże się z powstaniem Solidarności i zainteresowaniem nowymi, niesionymi przez ten czas gorących szesnastu miesięcy, wyzwaniami. Drugą debatę wytoczył Tischer marksizmowi, wydaną 1979 roku w podziemiu, książką Polski kształt dialogu. Po niej publikował też inne, już mnie obszerne teksty. Odpowiedź strony marksistowskiej przyszła z kręgu mniej znanych filozofów, takich jak Włodzimierz Lebiedziński ${ }^{3}$ i Józef Kwapiszewski ${ }^{4}$. Polemiki nie były tak inspirujące, jak w pierwszej debacie, i spór dość szybko wygasł ${ }^{5}$. Trzecia debata, o której chciałbym szerzej napisać $\mathrm{w}$ tym artykule, była w „przygotowaniu”. Wydaje się, że ten nowy spór byłby sporem z liberalizmem i głoszonym przezeń sposobem rozumienia wolności.

Po upadku systemu komunistycznego w Polsce (a także w innych krajach Europy Środkowo-W schodniej) marksizm przestał być znaczącą siłą polityczną. Idee, którymi się podpierał, uzasadniając swoje prawo do monopolu władzy, także straciły na znaczeniu i popularności. Równocześnie ze słabnięciem marksizmu na znaczeniu zyskiwał liberalizm, i to zarówno w aspekcie gospodarczym i politycznymi (mniej społecznym), jak i kulturotwórczym. Jednakże analiza i poszukiwanie zrozumienia jego istoty nie były uważane za interesujące wyzwanie dla elit intelektualnych odzyskującej niepodległość Polski. Ważne było, że liberalizm

2 Pisali o niej między innymi: K. Tarnowski, Tomizm a obecność filozofii, „Znak” (1978) nr 2, s. 198-212; Z. Dymarski, Debata księdza Józefa Tischnera ze szkołą lubelską, „Logos i Ethos” (1998) $\mathrm{nr}$ 1, s. 235-245; M. Jawor, W stronę egzystencjalnego oblicza filozofii, Olsztyn 2019; S. Dąbrowski, Polemika Józefa Tischnera $z$ tradycją tomistyczna jako spór o ksztatt wspótczesnej edukacji religijnej $w$ Polsce, „Forum Pedagogiczne” (2019) nr 2, s. 93-105.

3 Mam tu na myśli dwie książki Włodzimierza Lebiedzińskiego: Tischnerowska metoda krytyki socjalizmu, Warszawa 1987 oraz Socjalizm w krzywym zwierciadle Józefa Tischnera, Warszawa 1985.

4 J. Kwapiszewski, Filozofia ks. Józefa Tischnera jako źródło dialogu, Słupsk 1998.

5 Debata ta, jak na razie, nie doczekała się opracowania. Pisał o niej Józef Maria Ruszar w Wokót „Polskiego kształtu dialogu”. Polskie filozofowanie (artykuł ukazał się jako wkładka w:), „Rzeczpospolita” 16.02.2002, dodatek Plus Minus nr 7, s. D4 oraz S. Konstańczak, Józefa Tischnera krytyka marksi$z m u$, w: S. Konstańczak, Polska XIX i XX wieku w filozoficznym zwierciadle, Kraków 2017, s. 293316. Niektóre jej wątki zasygnalizowałem w eseju Józef Tischner wobec marksizmu. Wstępne rozpoznania, „Karto-Teka Gdańska” (2020) nr 1, s. 116-130. 
przychodzi z Zachodu, gdzie święcił triumfy i przyniósł niespotykany nigdzie indziej na świecie rozwój ekonomiczny i kulturalny.

Liberalizm w centrum swych zainteresowań stawia sprawę wolności.

Pytania o wolność, jej naturę, źródła, zakres i granice, ze względu na sprawę człowieka, interesowały również Józefa Tischnera i Leszka Kołakowskiego. Odpowiadali na te pytania w różny sposób. Różnice te - moim zdaniem - mogłyby być centralnym przedmiotem sporu pomiędzy filozofami. Sporu możliwego, lecz jednak niedoszłego. Powodów, dla których do tego intelektualnego pojedynku nie doszło, było wiele. Wydaje się, że miały one po części charakter praktyczno-życiowy, po części towarzyski. Myślę, że obu filozofów w tym czasie (lata 9o.) bardzo wciągnęło bieżące życie polityczno-intelektualne. $\mathrm{Z}$ racji swoich szerokich horyzontów intelektualnych byli oni często proszeni o skomentowanie aktualnej sytuacji albo o udział $\mathrm{w}$ dyskusjach dotyczących bieżących spraw. Niestety, najczęściej przyjmowali te zaproszenia. A uczestnictwo w nich absorbowało sporo czasu i sił twórczych. Były też zagadnienia, na które patrzyli w podobny sposób. Świadomość ich istnienia raczej osłabia niż wzmacnia chęć wejścia w zasadnicze spory. Należy też pamiętać, że $w$ tym czasie obaj filozofowie darzyli się nawzajem szacunkiem, a nawet przyjaźnią, to zaś sprawiało, że intensywne myślenie o różnicach $\mathrm{w}$ rozumieniu niektórych zagadnień filozoficznych nie wydawało się takie istotne.

„Wolność" to termin, którym posługujemy się w różnych kontekstach. Myślę, że w aspekcie antropologicznym najistotniejsze jest poczynione przez Leszka Kołakowskiego rozróżnienie na wolność zewnętrzną (nazywaną przez niego także wolnością prawną) i wolność wewnętrzną.

1. W wolności zewnętrznej chodzi o zakres swobody do działania w przestrzeni społecznej. Rozumienie wolności związane jest tu z życiem zbiorowym. Obszar swobodnego działania w tej przestrzeni określany jest przez charakter kultury, to jest przez obyczajowość, tradycję polityczną, realizowaną przez władzę politykę społeczną i przez stanowione prawa. Tu obywatel, członek danej społeczności, ma tym więcej wolności, im mniejsze ograniczenia (np.podróżowania, wypowiedzi, publikacji, 
działań w przestrzeni publicznej...) nakłada na niego władza polityczna oraz społeczność, w której żyje ${ }^{6}$. Wolność ta jest stopniowalna: jest ona tym większa, im więcej decyzji odnośnie do swojego życia i możliwości wpływania na funkcjonowanie państwa i społeczności lokalnych pozostaje w rękach samych obywateli ${ }^{7}$. Tak rozumianą wolność mamy na myśli, gdy oceniamy systemy polityczne jako mniej lub bardziej liberalne. W takim rozumieniu pełna (acz nierealizowalna w praktyce) wolność miałaby miejsce wtedy, gdyby władza nic ludziom nie nakazywała i niczego nie zabraniała. Natomiast stalinowską Rosję i Koreę Północną należałoby uznać za kraje, gdzie zakres owej wolności jest najmniejszy. Warto też zauważyć, że dla władz wielu krajów (nie tylko wymienionych) ograniczanie tak rozumianej wolności motywowane jest często (nie zawsze słusznie) potrzebą zapewnienia ludziom bezpieczeństwa.

2. W przypadku wolności wewnętrznej, nas tu bardziej interesującej, chodzi o autorstwo podejmowanych decyzji, a więc o sprawę niezwykle istotną dla ludzkiej podmiotowości. Treści zawarte w odpowiedzi na pytanie - o to, w jakim stopniu to człowiek jest autorem swoich wyborów, a w jakim jakieś inne czynniki będące poza kontrolą jego świadomości rozstrzygają o sposobie rozumienia natury ludzkiej. Dlatego rozpoznanie tego, co Kołakowski określa jako „duchowe warunki wyboru”, jest niezwykle ważne dla określenia charakteru sprawczości człowieka. Czy on jest autorem swoich czynów czy też tylko przekaźnikiem mocy, nad którymi nie ma władzy. Spór o tę wolność jest w pewnym sensie pokrewny sporowi o powszechny determinizm; nie jest $\mathrm{z}$ nim jednak tożsamy.

Dlatego rozpoznanie poglądów Kołakowskiego i Tischnera na naturę ludzkiej wolności wewnętrznej musi być poprzedzone rozpoznaniem „duchowej strony człowieka”.

6 „W najszerszym znaczeniu «władzą» nazywamy wszystko, co pozwala nam wpływać na otoczenie - naturalne czy ludzkie - w pożądanym kierunku" (L. Kołakowski, Mini wykłady o maksi sprawach, t. 1, Kraków 1997, s. 7).

7 Ciekawie o tym sposobie rozumienia wolności pisze Kołakowski w eseju Gdzie jest miejsce dzieci w filozofii liberalnej?, w: L. Kołakowski, Moje słuszne poglądy na wszystko, Kraków 2000, s. $170-185$.

${ }^{8}$ L. Kołakowski, Mini wykłady o maksi sprawach, dz. cyt., s. 83. 


\section{Człowiek i wolność według Leszka Kołakowskiego}

Charakteryzując człowieka, Kołakowski wskazuje na pięć aspektów tożsamości osobowej. Są to: rdzeń osobowości, pamięć, antycypacja, ciało i świadomość początku9. Przez wieki, aż do czasów kartezjańskich, oczywiste było to, iż to dusza - w rozmaity sposób wiązana przez filozofów (Platon, Arystoteles, Kartezjusz) z ciałem - stanowi o tożsamości osobowej ${ }^{10}$. David Hume zakwestionował ten pogląd, wskazując na nieempiryczność kategorii substancji. W świetle jego krytyki dusza może mieć jedynie status postulatu metafizycznego. Kołakowski jest przekonany jednak, iż wywody szkockiego empirysty nie przekreślają możliwości istnienia desygnatu terminu $\mathrm{Ja}^{11}$.

Filozof uważa, że za istnieniem rdzenia osobowości przemawiają trzy istotne racje. Związane są one $\mathrm{z}$ doświadczeniem wewnętrznym, odpowiedzialnością osobistą oraz z niezastępowalnością osoby. Kołakowski jest przekonany, że pewność istnienia Ja uzyskuje każdy człowiek w doświadczeniu wewnętrznym. Po prostu wie, że „Ja jestem Ja”. Po drugie, istnienie rdzenia osobowości jest według filozofa warunkiem istnienia osobistej odpowiedzialności; i w sensie odpowiedzialności karnej, i w sensie bycia uczestnikiem życia społecznego ${ }^{12}$. I po trzecie, tylko

9 Zob. L. Kołakowski, O tożsamości zbiorowej, w: Tożsamość w czasach zmiany, red. K. Michalski, Kraków 1995, s. 45-48.

10 Tożsamość osobowa to relatywnie młoda kategoria. Myślenie o sobie jako o kimś, kto samodzielnie stanowi o tym, kim chce być, jest owocem ery nowożytnej. Według Charlesa Taylora dyskusja „na temat «tożsamości» w nowoczesnym sensie tego słowa byłaby niezrozumiała dla ludzi żyjących kilka stuleci temu” (Ch. Taylor, Źródła podmiotowości, tłum. A. Lipszyc, Warszawa 2001, s. 54).

11 Warto tu też zauważyć, że w polskiej literaturze filozoficznej (i nie tylko filozoficznej) funkcjonuje wiele terminów próbujących dookreślić to, co swoiście ludzkie, niepowtarzalne i nadające charakter człowieczeństwu, takich jak na przykład jaźń, podmiot, osobowość, osoba ludzka, Ja, sobość. Sam Kołakowski nie jest tu konsekwentny. Na przykład w eseju raz posługuje się terminem osobowości (zob. L. Kołakowski, Odpowiedzialność, w: Moje słuszne poglądy na wszystko, dz. cyt., s. 203, 206), a kiedy indziej podmiotowości (zob. L. Kołakowski, Odpowiedzialność, dz. cyt., s. 209), Ego (zob. L. Kołakowski, Odpowiedzialność, dz. cyt., s. 211) oraz osoby ludzkiej (zob. L. Kołakowski, Odpowiedzialność, dz. cyt., s. 206).

12 „Wiara w nieredukowalny i niepowtarzalny rdzeń osobowości nie jest z pewnością naukowo dowodliwą prawdą [...], ale pojęcie godności osobistej i praw ludzkich jest bez tej wiary 
jego istnienie gwarantuje nieredukowalność jednostek do uwarunkowań społecznych i historycznych ${ }^{13}$.

Następny aspekt tożsamości osobowej to pamięć. Ona jest według Kołakowskiego warunkiem ciągłości. Filozof, podobnie jak Augustyn, uważa, że pamięć uobecnia przeszłośćc ${ }^{14}$. Przeszłość bliska stanowi jeszcze część teraźniejszości, a przeszłość daleka jest powtórnie przypomniana. Ona, poprzez przywoływanie przeszłości, uprzytomnia człowiekowi wiedzę o tym, jaką drogę w życiu przebył, skąd wywodzą się jego przodkowie i kim są jego sąsiedzi. Pielęgnowanie wspomnień i uczenie się historii odległych czasów warunkuje zatem ciągłość świadomości ${ }^{15}$. Kołakowski zauważa, że przeszłość uobecniana może być budowana warstwowo, poprzez nadbudowywanie warstwy nad warstwą. Może zatem wzrastać $\mathrm{w}$ podobny sposób, jak narastają $\mathrm{z}$ roku na rok słoje drzewa. Może też zmieniać się jak żywy organizm, który rozwija się nieproporcjonalnie, ale rosnąc, zachowuje strukturę początkową. Jaka jest natura pamięci, tego filozof ostatecznie nie rozstrzyga. Ważniejsze niż rozstrzygnięcie, która $\mathrm{z}$ koncepcji jest prawdziwa, wydaje się to, co wspólne obu koncepcjom, czyli przekonanie, że człowiek nie jest tylko z teraźniejszości. Istotne jest to, że jest „człowiekiem historycznym”, a nie „nihilistycznym” ${ }^{16}$.

arbitralnym wymysłem, zawieszonym w próżni, nie nadającym się do obrony, łatwym do zlekceważenia" (L. Kołakowski, Moje słuszne poglądy na wszystko, dz. cyt., s. 256).

13 Istnienie rdzenia osobowości stoi na straży swoistości i niepowtarzalności człowieka i falsyfikuje głoszoną przez Karola Marksa tezę o wymienialności jednostek ludzkich. Była to „zasada - praktykowana inaczej [w Cywilizacja na ławie oskarżonych, Warszawa 1990, s. 312 przełożono jako „raczej”] niż wprost wysławiana - wedle której jednostki ludzkie są całkowicie wymienialne, a życie jednostek liczy się o tyle tylko, o ile są one narzędziami sprawy ogólnej, czyli państwa [...]" (L. Kołakowski, Moje słuszne poglądy na wszystko, dz. cyt., s. 365).

14 Zob. Augustyn, Wyznania, tłum. Z. Kubiak, Kraków 1994, Księga XI, 28.

15 Podobne spojrzenie na tę kwestię ma Taylor. Pisze na przykład: „jako istota, która rozwija się i staje, mogę znać samego siebie tylko poprzez moją historię dojrzewania i regresji, historię zwycięstw i klęsk. Moje samorozumienie ma z konieczności czasowy wymiar i opiera się na narracji” (Ch. Taylor, Źródła podmiotowości, dz. cyt., s. 100).

${ }^{16}$ L. Kołakowski, Czy „człowiek historyczny” umarł i czy powinniśmy jego zgon opłakiwać?, w: L. Kołakowski, Moje słuszne poglady na wszystko, dz. cyt., s. 100-115. 
Należy uznać, że częścią tej pamięci - chociaż Kołakowski wymienia ją jako kolejny aspekt tożsamości osobowej - jest świadomość początku. Myślę, że wydobywa ją z oceanu świadomościowych zdarzeń i podkreśla jej znaczenie $\mathrm{z}$ dwóch powodów. Po pierwsze dlatego, że człowiek pamięta niewiele swoich początkowych przeżyć, w związku z czym przy odtwarzaniu świadomości początku podpiera się wyobraźnią i późniejszą wiedzą o tym, jak ten początek wygląda u innych, młodszych od niego (i których rozwój może już świadomie obserwować). W związku z tym status świadomościowy początku jest nieco inny niż status przeżyć, które pamięta jako bezwątpliwościowo zaszłe. Po drugie dlatego, że uważa, iż „moment i miejsce wyjścia” są niezwykle ważne. Posiadanie świadomości początku oznacza, że człowiek nie jest znikąd. Nie jest jak przedmiot lub część zamienna (której można użyć do naprawy wielu różnych urządzeń), lecz jest istotą niepowtarzalną oraz wyjątkową i dlatego od samego początku zakorzenioną w kulturze miejsca i czasu swych narodzin. Człowiek związany jest także z innymi ludźmi, w tym przypadku rodzicami, którzy go na ten świat powołali ${ }^{17}$.

Następnym wymienianym przez Kołakowskiego aspektem tożsamości osobowej - będącym w pewnym sensie na drugim biegunie pamięci (w stosunku do świadomości początku) - jest ukierunkowanie na przyszłość. Nie jest ono chłodnym kalkulowaniem, podpartym szacunkiem sił i możliwości, ale wychyleniem świadomości - z pewnymi obawami, ale również z nadzieją i radością ${ }^{18}$ - ku temu, co nadejdzie.

17 O tym, jak ważna jest pamięć początku, świadczą rozmowy Anny Herbich pomieszczone w książce Dziewczyny ocalone (A. Herbich, Dziewczyny ocalone, Kraków 2020). Jej interlokutorki, Żydówki, które przeżyły II wojnę jako dzieci w polskich rodzinach, nie znając swych korzeni, nie znając swych biologicznych rodzin, tęsknią za żydowskością. Tęsknią za drugą częścią swej tożsamości. Anna Herbich w wywiadzie mówi o nich: „ci ludzie tęsknili za żydowskością, mieli poczucie, że to ich tożsamość, ich historia, ich przedwojenne życie. Byli więc rozerwani. Chcieli się wtopić w społeczeństwo, ale z drugiej strony nie chcieli się odcinać od korzeni” (A. Herbich, A. Sobańda, Dziś mają dzieci, wnuki i prawnuki. W ten sposób pokonaly Hitlera, https://kultura.dziennik.pl/ksiazki/artykuly/6477152,dziewczyny-ocalale-zyd-zydowka-wojna-holocaust-anna-herbich-wojna-sprawiedliwi.html (6.10.2020)).

18 Inaczej niż Gabriel Marcel i Józef Tischner, Leszek Kołakowski określa je tylko jako emocje. 
Ostatni aspekt tożsamości osobowej stanowi według Leszka Kołakowskiego ciało. Pisze on „ciało”, ale przedstawiona w eseju charakterystyka dotyczy bardziej świadomości ciała niż ciała jako takiego. Prawdopodobnie poprzez posłużenie się terminem „ciało” filozof chciał wyrazić pogląd, że według niego tożsamość osobowa jest nieodrywalna od ciała, tego właśnie konkretnego ciała. Kołakowski czyni świadomość cielesności składową tożsamości osobowej, aby podkreślić odmienność swojego stanowiska w stosunku do stanowiska Johna Locke'a. Angielski filozof dopuszczał bowiem możliwość migracji świadomości między ciałami ${ }^{19}$. Według Kołakowskiego, dzięki świadomości cielesności, człowiek jest nieprzerwanie w bliskim związku z ciałem. Mimo obserwowanych i doświadczanych zmian ciała, jest przekonany, iż jest to jego ciało. Doświadcza, że właśnie poprzez to, a nie inne ciało, jest (nieprzerwanie) włączony $\mathrm{w}$ świat.

Należy zauważyć, że opisane powyżej składowe tożsamości osobowej, to jest świadomość początku i ukierunkowanie na przyszłość, a także pamięć, są częścią świadomości szerzej pojmowanej. Można zatem powiedzieć, że Leszkowi Kołakowskiemu bliska jest koncepcja człowieka, którą należy określić jako świadomościową. Centralne miejsce zajmuje w niej wspomniany już „rdzeń osobowości”, a świadomość początku, ukierunkowanie na przyszłość oraz pamięć stanowią jego aspekty.

Tak szeroko rozumiany „rdzeń osobowości” w starożytnej Grecji był utożsamiany z duszą. Potem, na przestrzeni wieków, jego rozumienie ewoluowało. Kołakowski nie ujawnia natomiast tego, czym miałby on być w świetle współczesnych badań. Niewiele też pisze o swoich poglądach na ten temat.

Charakterystyka tożsamości osobowej zamieszczona w eseju O tożsamości zbiorowej ma charakter strukturalny i nie daje podstaw do stwierdzenia, jaka miałaby być natura najważniejszych treści, wokół których tożsamość byłaby nabudowywana. Pewnego tropu dostarcza jedynie

19 Zob. J. Locke, An Essay Concerning Human Understanding, Oxford 2008, 2.27.12. Pomijam tu całkowicie faktyczną wykonalność neurologiczno-biologiczną takiej operacji na człowieku. 
stwierdzenie, że „istnieje dziedzina realności osobowych, którą określać trzeba w kategoriach moralnych, nie biologicznych"20.

Myślę jednak, że poglądy Kołakowskiego na tę kwestię są bardzo ważne dla zrozumienia jego filozofii i dlatego należy podjąć próbę ich zrekonstruowania. Pomocne będzie nawiązanie do filozofii Arystotelesa i Johna Locke’a. Według Arystotelesa zachodzi związek między wrodzonymi predyspozycjami człowieka a realizowanymi przez niego działaniami. Człowiek rozwija najskuteczniej te cnoty, które mają oparcie w jego naturalnym usposobieniu. Inaczej jest u Locke’a. Respektuje on kartezjańską wizję człowieka jako połączenia substancji myślącej i substancji rozciągłej, ale odrzuca istnienie idei wrodzonych. Według Locke’a człowiek jest przede wszystkim substancją myślącą, czyli świadomością. Jej aktywność związana jest z identyfikacją celów (z których najważniejszym jest szczęście, często powiązane z przyjemnością) i podjęciem działań mających doprowadzić do ich osiągnięcia. Nie własne predyspozycje, ale najkorzystniejsze rezultaty stają się tu drogowskazem. By osiągnąć pożądane cele, świadomość (a więc centrum człowieka) gotowa jest do bardzo radykalnych działań, nawet do przekształcania samej siebie. Jest to możliwe dlatego, że tożsamość jednostki opiera się na rozumie (pojmowanym instrumentalnie), a nie na wierności wrodzonym predyspozycjom. Rzeczywista podmiotowość istnieje zatem jedynie jako władza zaprowadzania obranego przez siebie porządku. Można powiedzieć, że jest władzą manipulowania rzeczami. John Locke pisze: „Moc, która decyduje, że władze wykonywujące działania w poszczególnych przypadkach wytwarzają ruch albo zachowują spoczynek, nazywamy wolą" ${ }^{21}$. Charles Taylor, by podkreślić tę wolnościową (czyli niezwiązaną z żadnymi stałymi cechami lub wartościami) naturę świadomości w ujęciu Johna Locke’a, wprowadził określenie „sobość punktowa”22.

20 L. Kołakowski, Bałwochwalstwo polityki, w: Moje słuszne poglądy na wszystko, dz. cyt., s. 259.

21 J. Locke, An Essay Concerning Human Understanding, dz. cyt., 2.21.71.

22 Polski tłumacz pracy Taylora posługuje się terminem „podmiotowość punktowa” (w wydaniu polskim s. 321). Wydaje mi się, że lepiej intencję Taylora (i w pewnym sensie Johna Locke’a), odnośnie do określenia „punktual self” (w wydaniu angielskim s. 171) oddaje zwrot „sobość punktowa". 
Także Leszek Kołakowski uważa, że wolność ma wielkie znaczenie w „konstrukcji” człowieka ${ }^{23}$. Pisał o tym wielokrotnie. Na przykład w minieseju $O$ wolności stwierdzał, że „wolność jest [...] dana ludziom razem $\mathrm{z}$ ich człowieczeństwem, jest tego człowieczeństwa fundamentem, tworzy człowieka jako coś w bycie samym wyróżnionego"24. Zatem, zdaniem filozofa, wolnościowy charakter duchowego centrum człowieka ma oparcie w doświadczeniu oraz w fakcie godności człowieka. Kołakowski uważa, że wolność jest „doświadczeniem elementarnym”25 człowieka i doświadcza jej każdy, wybierając. A idąc za Lockiem, dodaje, że jest ono „tak elementarne, że nierozkładalne na części, które dałoby się z osobna analizować" ${ }^{26}$. Przyznaje więc, że bycia wolnym nie sposób wykazać w sposób analityczny, ale poczucie bycia sprawcą realizowanych działań jest na tyle jasne i mocne, że nie ma powodów temu doświadczeniu nie zaufać. Uważa też, że wolność jest gwarantem wyjątkowości człowieka. U progu ery nowożytnej dał temu wyraz Giovanni Pico della Mirandola w Mowie o godności człowieka ${ }^{27}$.

Zatem według Leszka Kołakowskiego wolność odgrywa znaczącą rolę w konstrukcji „duchowego centrum człowieka”, ale nie jest jego jedynym „tworzywem”. Zdaniem filozofa świadomość nie jest tylko siłą zdolną do manipulacji (w szerokim sensie tego słowa). Nie jest zatem punktowa, czyli według niego nie jest radykalnie inna niż otaczająca ją rzeczywistość. Nie stanowi wyspy „ducha” na morzu „materii”. Jest powiązana z kulturą, czyli z wytworami ludzi, którzy żyli przed nim,

${ }^{23}$ Chociaż zauważyć należy, że w zamieszczonej w eseju O tożsamości zbiorowej charakterystyce tożsamości osobowej Kołakowski nie wspomina o wolności. Dlaczego tak czyni? Myślę, że powodem jest dla niego oczywistość wolności.

24 L. Kołakowski, Mini wykłady o maksi sprawach, dz. cyt., s. 81.

25 L. Kołakowski, Mini wykłady o maksi sprawach, dz. cyt., s. 80

26 L. Kołakowski, Mini wykłady o maksi sprawach, dz. cyt., s. 80-81.

27 Według Pico della Mirandoli Bóg powiedział do pierwszego człowieka: „Ustanowione przez Nas prawa ograniczają określoną naturę innych stworzeń. Ty, niczym nieograniczony, dzięki swej woli, w której mocy cię pozostawiłem, sam ją sobie wyznaczysz. [...] Możesz wyrodzić się w niższe stworzenia, w zwierzęta, możesz zostać odrodzony dzięki postanowieniom twojego umysłu w istotach wyższych i boskich" (G. Pico della Mirandola, Mowa o godności człowieka, tłum. Z. Nerczuk i M. Olszewski, Warszawa 2010, s. 39). 
i tych, którzy współcześnie żyją wokół niego. „Osobowość wszakże jest zjawiskiem nie tylko "egzystencjalnym», lecz również kulturowym"28.

Kultury są bogate $\mathrm{w}$ symbole i wartości. Jednak niektóre z nich (na skutek różnych przyczyn, takich jak na przykład długość istnienia, otwartość na inne kultury albo wreszcie własne założenia fundamentalne) nie tworzą zwartych systemów. Takie kultury są bogate w różne, im właściwe, treści i wartości, których zwartość i spójność ma charakter dynamiczny $\mathrm{i}$ jest $\mathrm{w}$ ciągłym procesie uzgadniania warunków współistnienia. Do takich kultur można zaliczyć na przykład cywilizację europejską. Tak że człowiek, uczestnik takiej kultury, niektóre wartości dziedziczy na skutek urodzenia się, a potem wzrastania $\mathrm{w}$ tej kulturze, a niektóre wybiera samodzielnie. Charakter wyboru związany jest według Kołakowskiego z indywidualną sytuacją egzystencjalną człowieka ${ }^{29}$. Poprzez swoje indywidualne wybory ludzie wpływają, w większy lub mniejszy sposób, na kierunek wewnątrzkulturowej dynamiki uzgodnień wartości.

Kołakowski podkreśla nierozłączność człowieczeństwa i wolności (rozumianej jako bycie zdolnym do wolnych wyborów). Jest przekonany, że na fakt bycia wolnym nie ma wpływu treść tychże wyborów. Opowiadając się za przekonaniem, że człowiek jest wolny niezależnie czy wybiera zło czy też dobro, Kołakowski staje w opozycji do takich myślicieli, jak Immanuel Kant, Augustyn oraz Józef Tischner. O wolności rozstrzyga fakt wybierania, a nie treść wyborów. Jego zdaniem pogląd odmawiający człowiekowi wolności, gdy wybiera on zło lub fałsz, „niszczy idee odpowiedzialności osobistej, jaką każdy z nas winien mieć, za własne życie" ${ }^{30}$. Człowiek jest człowiekiem, bo jest wolny. Odmawianie mu sprawczości dokonywanych czynów byłoby tym samym zaprzeczaniem jego człowieczeństwu.

Człowiek jest istotą rozumną i świadomą, działając w świecie, kieruje się swoimi racjami. Wynikają one $\mathrm{z}$ jego wiedzy, orientacji $\mathrm{w}$ świecie

28 L. Kołakowski, O tożsamości zbiorowej, dz. cyt., s. 48.

${ }^{29}$ O pewnych elementach i warunkach tych wyborów pisałem w eseju Człowiek jako rozumna wolność. Droga Leszka Kołakowskiego do filozofii człowieka, w: Rozum i przestrzenie racjonalności, red. A. Chmielecki, Gdańsk 2010, s. 81-98.

${ }^{30}$ L. Kołakowski, Odpowiedzialność, dz. cyt., s. 203. 
i planów. Większa wiedza pomaga czynić wybór bardziej kompetentnym i może skuteczniejszym. Mniejsza - mniej przygotowanym, mniej trafnym. Jest to jednak jego (to jest człowieka) wybór, a więc wybór wolny. I za jego skutki on, jego autor, ponosi odpowiedzialność.

Leszek Kołakowski dokładnie wyjaśnia, jaki rodzaj odpowiedzialności ma tu na myśli. Nie chodzi mu o odpowiedzialność w sensie zobowiązania do sprawowania opieki bądź dozoru nad czymś (np. statek, miejsce pracy), bądź w sensie sprawstwa jakiegoś dzieła lub autorstwa czynu (zarówno konstruktywnego, jak i niszczycielskiego). Chodzi mu natomiast o odpowiedzialność za konsekwencje wyboru i wynikającego z niego czynu. Ktoś podjął jakieś działania i jest winny w sensie moralnym (nawet gdy prawo tego nie obejmuje). Zdaje sobie sprawę $\mathrm{z}$ tego, że to, co robi lub zrobił, będzie miało pewne, zawsze konkretne, konsekwencje (albo mówiąc inaczej efekty) dla jego otoczenia, świata i niego samego ${ }^{31}$.

Według Kołakowskiego wina, a więc moralna ocena wyborów i powiązanych z nimi czynów, nie jest kulturowo niezmienna. Uważa, że kryteria tego, co dobre, a co złe, są powiązane $\mathrm{z}$ fundamentalnymi zasadami cywilizacji, w której człowiek żyje. Współtworząca tę cywilizację religia (w przypadku Europy jest to chrześcijaństwo) nie tylko dostarcza objaśnień o prawdziwej naturze rzeczywistości i sensie ludzkiej egzystencji, lecz w oparciu o te rozpoznania podaje, czym jest dobro, a czym zło. Wyjaśnianie, dlaczego tak, a nie inaczej przebiega granica między dobrem a złem, opiera na mającej umocowanie w mitach koncepcji sacrum ${ }^{32}$. Przekroczenie tabu (druga, groźniejsza strona sacrum) oznacza zakwestionowanie przez człowieka swojego statusu w porządku kosmicznym (to znaczy także i społecznym) oraz narusza stabilność, a co za tym idzie - trwanie samego kosmosu. Rodzi też poczucie winy ${ }^{33}$.

31 Zob. L. Kołakowski, Odpowiedzialność, dz. cyt., s. 202-211.

32 Jak według Kołakowskiego przebiega ta granica w społecznościach silnie zlaicyzowanych, staram się wyjaśnić w artykule Z. Dymarski, Gdzie jest zło? Rola religii w lokalizacji zła w ujęciu Leszka Kołakowskiego i Józefa Tischnera, „Humaniora” (2017) nr 2, s. 47-61.

33 Doświadczenie winy „nie jest aktem intelektualnym, ale aktem, w którym kwestionuje się własny status w porządku kosmicznym [...] nie jest to strach przed odwetem, lecz poczucie grozy 
Kołakowski uważa, że konsekwencje zło-czynienia odnoszą się zarówno do ładu kosmosu, jak i do samego zło-czyńcy - nie oznacza to jednak według niego tego, iż człowiek jest przez to sprawstwo jakoś zniewalany. Wybranie przez człowieka zła, czyli zgrzeszenie (posługując się kategoriami chrześcijańskimi), czyni zło-czyńcę grzesznikiem, ale nie niszczy go wewnętrznie i nie zniewala. Tym samym filozof nie uważa, iżby grzech, czyli nieposłuszeństwo Bożym (mającym oparcie w naturze rzeczywistości) zaleceniom i nakazom, pętał w jakiś sposób ludzką wolę. Grzech nie sprawia więc, że następne wybory nie są wolne. Kołakowski pisał, że nie sądzi, iż: „gdy nie jesteśmy prawdzie w tym sensie posłuszni, tracimy wolność wyboru, że więc nie używamy swej wolności wybierania, kiedy czynimy zło" ${ }^{34}$. Tą deklaracją wskazuje na to, że - w sięgającym jeszcze starożytności sporze między Pelagiuszem a Augustynem filozof zajął umiarkowane, to znaczy semipelagiańskie ${ }^{35}$ stanowisko.

Leszek Kołakowski wielokrotnie pisał, że człowiek jest wolny, to znaczy zdolny do wybierania między różnymi możliwościami oraz do tworzenia ${ }^{36}$. Tak rozumiana wolność jest według niego fundamentem człowieczeństwa. Ona wyróżnia człowieka spośród innych istot i daje mu szczególną pozycję we wszechświecie. Ale nie jest to sytuacja bezwyjątkowa.

Zdarza się, że człowiek zachowuje się tak, iż nie może być dłużej nazywany człowiekiem. Tę tezę formułuję w odwołaniu do analiz przeprowadzonych przez Kołakowskiego i pomieszczonych później w eseju $W y$ chowanie do nienawiści, wychowanie do godności. Filozof, przemawiając we Frankfurcie nad Menem, w październiku 1977 roku, na uroczystości

w obliczu własnego czynu, który zakłócił harmonię świata" (L. Kołakowski, Jeśli Boga nie ma... O Bogu, Diable, Grzechu i innych zmartwieniach tak zwanej filozofii religii, Kraków 1988, s. 210).

34 L. Kołakowski, Prawda i wolność, co pierwsze?, „Znak” (1994) nr 3, s. 72.

35 Kołakowski pisze zresztą o tym wprost: „piszący niniejsze, mający niejaką sympatię do semi-pelagiańskiej herezji” (L. Kołakowski, Prawda i wolność, co pierwsze?, dz. cyt., s. 72).

36 Kołakowski uważa, że w takim ujęciu wolności chodzi o „nasze własne duchowe warunki wyboru i tworzenia, o sam fakt, że wybierać i tworzyć jesteśmy władni, chociaż zdolność ta nasza nie zakłada niczego co do zakresu dóbr, wśród których faktycznie wybierać możemy" (L. Kołakowski, Mini wykłady o maksi sprawach, dz. cyt., s. 83). 
wręczenia mu przez księgarzy niemieckich pokojowej nagrody ${ }^{37}$, dzielił się z jej uczestnikami (głównie niemieckimi) swoimi refleksjami wyrosłymi na obserwacjach stosunków narodowych i politycznych w Europie Środkowej. Uznał, że ta pokojowa nagroda jest dobrą sposobnością do opowiedzenia - w odwołaniu do historii tego regionu i własnych doświadczeń z okresu wojny i nieodległego powojnia - o nienawiści ${ }^{38}$.

Człowiek buduje się wewnętrznie w porozumieniu z innymi ludźmi. Do właściwego rozwoju potrzebuje przyjaźni, zaufania, życzliwości. Tymczasem nienawiść to według Kołakowskiego taka energia, która międzyludzkie porozumienia niszczy. Tym samym nie dopuszcza do wewnętrznego zintegrowania się człowieka. Obezwładniony duchowo człowiek przestaje być istotą myślącą i kontrolującą swoje słowa oraz zachowania. Nienawiść „niszczy [...] wewnętrznie tych, co nienawidzą [...] wypełnia ona całą przestrzeń duchową człowieka" ${ }^{39}$.

W pewnym zakresie nienawiść jest podobna do miłości. Zakochany jest bezkrytyczny wobec obiektu miłości. Nienawidzący zaś jest bezkrytyczny zarówno wobec obiektu nienawiści, jak i wobec samego siebie. Być krytycznym to znaczy potrafić odróżniać i wartościować. Tymczasem nienawiść odbiera człowiekowi takie umiejętności. I dlatego nienawidzącymi, jak zauważa Kołakowski, chętnie manipulują rządy stawiające sobie niecne cele. Nienawiść rodzi nienawiść i dlatego filozof uważa, że stanowi ona coś „więcej niż dążenie do zniszczenia. Podobnie jak miłość zawiera ona w sobie pewien rodzaj nieskończoności, nienasycenie. Nie dąży po prostu do zniszczenia, ale do nieustającego cierpienia, równa się przeto pragnieniu zostania diabłem, a natura diabła na tym właśnie polega, iż nie może zaznać nasycenia w dziele niszczenia" ${ }^{40}$.

Oznacza to, że możliwe są takie stany (raczej ekstremalne), w których człowiek zostaje zawłaszczony przez siły destrukcji, nad którymi nie

37 Zob. W. Chudoba, Leszek Kołakowski: kronika życia i dzieła, Warszawa 2014, s. 309.

38 Zob. L. Kołakowski, Z. Mentzel, Czas ciekawy. Czas niespokojny, t. 1, Kraków 2007, s. 39-82.

39 L. Kołakowski, Wychowanie do nienawiści, wychowanie do godności, w: L. Kołakowski, Czy diabeł może być zbawiony i 27 innych kazań, Londyn 1984, s. 143.

40 L. Kołakowski, Wychowanie do nienawiści, wychowanie do godności, dz. cyt., s. 142. 
ma władzy i nie ma możliwości wyboru. Należałoby zapytać, czy przekonanie o tym, że człowiek jest wolny, to znaczy zawsze zdolny do wolnych wyborów, nie jest aby częścią mitologii oświecenia?

\section{Wolny człowiek w ujęciu Józefa Tischnera}

Również według Józefa Tischnera rozpoznanie kwestii wolności winno być poprzedzone rozjaśnieniem sprawy człowieka. Odpowiedzieć na pytanie o człowieka, o to, kim jest w swej istocie, starało się wielu. Jednak według Tischnera ani Platon (koncepcja duszy uwięzionej w ciele), ani Arystoteles (koncepcja formy i materii współtworzących człowieka), ani Kartezjusz (świadomość władająca ciałem), ani Nietzsche (żywioł cielesności chcący wyzwolić się spod opresji ducha) nie byli w stanie uchwycić prawdziwie, czym człowiek w swej istocie jest. Przedstawiane przez filozofów opisy wydobywały najczęściej tylko jakiś aspekt człowieczeństwa, marginalizując lub czasami nawet pomijając pozostałe. Zdaniem Tischnera mankamentem tych i wielu innych proponowanych rozwiązań było też wykorzystywanie dystynkcji i kategorii pojęciowych, wypracowanych przy badaniu świata przedmiotowego, do opisu tego, co wyłącznie ludzkie.

Świadom trudności, świadom, iż tego, co swoiście i źródłowo ludzkie, nie da się zamknąć w pojęciach, starał się on znaleźć taką perspektywę spoglądania na człowieka, dzięki której można by w spójny sposób uchwycić jego (tj. człowieka) specyfikę. Według niego ta specyfika powinna być związana z takimi wyróżnikami człowieczeństwa, jak autonomia, samosterowność, rozumność, niepowtarzalność, przemijalność, odniesienie do otoczenia, „wychylenie ku”, ale też cielesność i zmysłowość.

Perspektywa bytowa, preferowana między innymi przez tomizm, prawie od razu wydała się Tischnerowi nieadekwatna ${ }^{41}$. Przez jakiś czas inspirowała go fenomenologia Edmunda Husserla i powiązana

41 Zob. J. Tischner, A. Michnik, J. Żakowski, Między Panem a Plebanem, Kraków 1998, s. 78-79. 
z nią koncepcja "ja transcendentalnego" ${ }^{42}$, ale ją też relatywnie szybko porzucił, gdyż znalazł bardziej adekwatne ujęcie. Uznał, że inspirowana teorią wartości Maxa Schelera koncepcja „ja aksjologicznego” jest tym ujęciem, którego poszukuje. Pracował nad nią przez wiele lat. Jej pierwsze opisy można znaleźć już w eseju zatytułowanym Impresje aksjologicz$n e^{43}$. Potem rozwijał ją w Myśleniu według wartości i w Filozofii dramatu. $\mathrm{Z}$ czasem jednak doszedł do wniosku, że i ta perspektywa ma pewne mankamenty. Związane one były z trudnościami w uchwyceniu fenomenu zła. Świadectwem tych zmagań są obszerne partie Filozofii drama$t u$. Kilka lat po opublikowaniu tej książki Tischner doszedł do wniosku, że najbardziej adekwatne będzie uchwycenie istoty człowieka z perspektywy agatologicznej ${ }^{44}$. To znaczy z perspektywy dobra - pojmowanego nie jako byt albo cecha bytu, ale - będącego w dynamicznym procesie, udzielania się. Dobro jest dla niego równie ważne jak dla Platona. Pojmował je jednak inaczej. Według niego ono jest ruchem, wychylaniem się, przekraczaniem siebie, wychodzeniem-ku, „jest tym, co z natury dąży do zaistnienia"45.

Koncepcję człowieka zbudowaną w oparciu o takie pojmowanie dobra zarysował Tischner w swojej ostatniej filozoficznej książce zatytułowanej Spór o istnienie człowieka. Człowiek, według niego, to świadoma istota zanurzona w dynamicznym życio-świecie. Duchowo „karmi się” zdarzeniami, które on mu „podsuwa”. W rezultacie „człowiek przede wszystkim «żyje tym, co przeżywa»"46. Przeżywanie to należy sytuować na wyższym poziomie niż instynkty, niżej jednak niż w pełni świadomą siebie samo-świadomość. Zdaniem Tischnera charakter i kierunek życiu człowieka nadaje to, co się mu (tj. przeżywającemu życie człowiekowi)

42 Efektem tego są dwa artykuły: Czym jest „ja” transcendentalne?, w: Szkice filozoficzne Romanowi Ingardenowi $w$ darze, Kraków-Warszawa 1964, s. 349-364 oraz Ja transcendentalne $w$ filozofii Edmunda Husserla, „Studia Theologica Varsoviensia” (1964) nr 1-2, s. 349-364.

43 J. Tischner, Impresje aksjologiczne, „Znak” (1970) nr 2-3, s. 204-219.

44 Już w opublikowanym w 1992 roku artykule Sprawa osoby - wstępne przybliżenie, „Logos i Ethos” (1992) nr 2, s. 5-19 widać, że zaczyna myśleć w żywiole agatologii. Podobnie w eseju Zło metafizyczne, czyli wejrzenie w otchłań, „Znak” (1993) nr 3, s. 13-28.

45 J. Tischner, Filozofia dramatu, Paryż 1990, s. 55.

${ }^{46}$ J. Tischner, Spór o istnienie człowieka, Kraków 1998, s. 278. 
wydarza. To nie odchodzi razem z mijającym czasem, ale poprzez człowieka i dzięki człowiekowi trwa. Według filozofa człowiek „«żyje dobrymi myślami», «żyje nadzieją», «żyje miłością»" ". Tischner współmyśli tu z Emmanuelem Lévinasem, który również uważał, iż człowiek żyje przeżyciami. Żyje na przykład „dobrą strawą, powietrzem, światłem, widokami, pracą, ideami, snem itd." ${ }^{48}$. Ten sposób bycia w świecie Emmanuel Lévinas określa terminem jouissance ${ }^{49}$. Człowiek żyje swą aktywnością, to znaczy tym, co robi, jak przeżywa i jak rozumie to, co robi ${ }^{50}$. Według Józefa Tischnera najważniejsze przeżycia są związane ze spotkaniami z innymi ludźmi. W spotkaniu jeden spotyka drugiego w jego biedzie. O tej biedzie mówi twarz spotkanego. Na niej wydarza się prawda człowieka ${ }^{51}$. Ludzi będących $w$ trudnej sytuacji Tischner symbolicznie określa jako obcokrajowca, wdowę oraz sierotę. Ten, który ich spotyka, może przejść obok nich obojętnie, może „nie chcieć” ich zauważyć, ale może też dostrzec ich biedę i starać się pomóc.

Zdaniem filozofa wydarzenie pomocy potrzebującemu ma pewną strukturę. Składa się ono z dwóch faz, z których pierwszą można określić jako etap „negatywny”, a drugą jako „pozytywny”. Najpierw spotykający odkrywa, że oto, na jego oczach, wydarza się coś, co wydarzyć się nie powinno. Drugi znajduje się w trudnym położeniu, dzieje mu się krzywda. To doświadczenie nazywa Tischner agatologicznym. Na bazie tej konstatacji spotykający projektuje działania, które doprowadzą do likwidacji dostrzeżonej biedy. To doświadczenie z kolei nazywa filozof aksjologicznym. „Doświadczenie aksjologiczne i płynące stąd myślenie

47 J. Tischner, Spór o istnienie człowieka, dz. cyt., s. 278-279.

48 E. Lévinas, Całość i nieskończoność. Esej o zewnętrzności, tłum. M. Kowalska, Warszawa 1998, s. 118.

49 Trudno ten termin przetłumaczyć na polski. Małgorzata Kowalska, tłumaczka Całości i nieskończoności przekłada jouissance jako „rozkoszowanie się”.

50 Lévinas pisze też: „Nie tylko istniejemy jako swoje cierpienie lub radość, ale też istniejemy poprzez cierpienia i radości. Rozkoszowanie się jest właśnie takim żywieniem się aktu swoją aktywnością". I dodaje też: „Żyjemy aktami - i nawet samym aktem bycia, tak jak żyjemy ideami i uczuciami. To, co robię, i to, czym jestem, jest jednocześnie tym, czym żyję" (E. Lévinas, Całość $i$ nieskończoność. Esej o zewnętrzności, dz. cyt., s. 119 i 121).

${ }^{51}$ O sposobach ukazywania się twarzy pisze Tischner w Filozofii dramatu (s. 58-70). 
aksjologiczne nastawia się na jeden podstawowy cel - projektowanie wydarzenia, które może zaradzić rozwojowi tragedii” ${ }^{\text {"2 }}$. Spotykający najpierw dostrzega zagubionego, potem pomaga mu znaleźć drogę. Najpierw poznaje biedną kobietę, potem pomaga jej znaleźć pracę, najpierw dostrzega sierotę, później podejmuje działania, by znaleźć mu opiekuna.

Tischner nie analizuje wydarzeń innych niż wydarzenia spotkania, takich na przykład, jak wiosenne prace polowe, budowanie pieca kaflowego, naprawa samochodu, reperowanie butów... Prawdopodobnie wynika to $z$ tego, iż uważa spotkania za najistotniejsze ${ }^{53}$. Sądzi bowiem, że de facto wszystkie one są sposobami międzyludzkiego dialogu. Wszak rolnik obsiewa pole, by urosło zboże, z którego piekarz upiecze chleb głodnym. Zdun buduje piec, by ludziom było ciepło w chłodne dni. Mechanik reperuje samochód, by lekarz mógł szybko dojechać do chorego. Szewc naprawia buty, by biedny miał w czym chodzić w zimie.

Jak widać, każdy czyn zmienia coś po stronie obdarowanego. Wpływa na sposób jego życia oraz na zmianę jego świadomości. Obdarowany będzie nie tylko wdzięczny za okazaną pomoc, ale prawdopodobnie zacznie też odzyskiwać wiarę $w$ innych ludzi. Powróci nadzieja na to, że możliwe są i lepsze życie, i lepsze relacje międzyludzkie.

Tischner zauważa jednak, że w wyniku dobro-czynienia powstaje jeszcze jeden skutek natury duchowej. Jest on związany z dobro-czyńcą właśnie. I on coś „zyskuje”. Efektem zwrócenia się Jednego (nazwę go Dar-czyńcą) ku Drugiemu, dostrzeżenia jego biedy i udzielenia mu pomocy jest zmiana wnętrza Darczyńcy. W przekonaniu Tischnera ludzkie wnętrze ma charakter agatologiczny, więc zachodząca zmiana ma nie-ontologiczny charakter.

Jak pisałem, każde wydarzenie na kształt, którego człowiek ma wpływ, związane jest $\mathrm{z}$ przeżyciem powiązanym z jakąś, zawsze konkretną,

52 J. Tischner, Myślenie według wartości, Kraków 1982, s. 491.

53 Definiując człowieka, Tischner odwoływał się do kategorii dramatu: „Człowiek jest istotą dramatyczną (Filozofia dramatu, dz. cyt., s. 11) oraz „Jesteśmy tacy, jaki jest nasz dramat” (Spór o istnienie człowieka, dz. cyt., s. 219). Nie jest to jednak dramat odgrywany w samotności. Jest odgrywany z ludźmi i wobec ludzi: „Jesteśmy osobami, czyli podmiotami dramatu wzajemności” (Spór o istnienie człowieka, dz. cyt., s. 219). 
wartością ${ }^{54}$. Wartości, powołane do istnienia przez człowieka, współtworzą jego obszar swojości. Przestrzeń ta jest odpowiednikiem tego, co w klasycznej filozofii określa się terminem „dusza”. Ma ona jednak według Tischnera charakter nie substancjalny, lecz agatologiczny ${ }^{55}$. Jego zdaniem kategorie ontologiczne nie są w stanie uchwycić natury tej przestrzeni. Uważa, że „jest to obszar, który rozciąga się całkowicie poza «byciem i niebyciem» - w którym, to, co jest, może nie być tym, czym jest, a to, co nie jest, może być tym, czym nie jest. Obszarem tym jest obszar Dobra. Natomiast «bytem», który zarazem jest i nie jest tym, czym jest, jest sama subiektywność. Subiektywność jest tym szczególnym «miejscem», w którym przejawia się gra Dobra z samym sobą" ${ }^{36}$.

Sam Tischner nie opisuje szczegółowo struktury przestrzeni wewnętrznej, ale myślę, że można - w oparciu o kilka jego wypowiedzi podjąć próbę jej rekonstrukcji. Mam tu na myśli komentarze do pracy doktorskiej Henriego Bergsona i do aksjologicznych koncepcji Maxa Schelera oraz fragment wywiadu z książki Przekonać Pana Boga.

Trafnie, jego zdaniem, ludzkie wnętrze opisuje Henri Bergson w książce $O$ bezpośrednich danych świadomości. Szczególnie istotny dla Tischnera jest rozdział O organizacji stanów świadomości. Francuski myśliciel umieścił w nim opis ludzkiej głębi, który Tischner uważa za bardzo trafny. Pisze Bergson: „Ale w miarę, jak schodzimy z tej powierzchni w głębie naszego ja, w miarę, jak nasze ja staje się znowu sobą, w tej mierze również stany świadomości przestają się szeregować, a poczynają się przenikać, zlewać się razem i zabarwiać każdy kolorem wszystkich innych. Każdy z nas ma swój sposób miłowania i nienawiści, a w tej miłości i w tej nienawiści odbija się cała nasza osobowość. Tymczasem mowa

54 Przy opisie budowy wewnętrznej przestrzeni świadomości filozof posługuje się zamiennie terminami „przeżycie” i „wartość”. Czyni tak dlatego, że są to dwie strony tego samego doświadczenia, przy czym używając terminu przeżycie, zwraca bardziej uwagę na jego genezę, a terminu wartość, by podkreślić jego etyczną wagę.

55 Tischner podkreśla tę niesubstancjalność na przykład w polemice z Mieczysławem A. Krąpcem i jego książką Ja-człowiek: „Dusza to pierwiastek istniejący poza przestrzenią i poza czasem. Ujmujemy go zatem czysto negatywnie: nie-czas, nie-przestrzeń. Ale czym on jest pozytywnie? Na to autor nie potrafi odpowiedzieć" (J. Tischner, Myślenie według wartości, dz. cyt., s. 334).

56 J. Tischner, Spór o istnienie człowieka, dz. cyt., s. 253. 
dla oznaczenia tych stanów stosuje te same słowa do wszystkich ludzi; toteż potrafiła tylko ustalić postać przedmiotową i nieosobową miłości, nienawiści i tysiąca uczuć poruszających duszę" 57 .

Tischner podobnie jak Henri Bergson uważa, iż przestrzeń wewnętrzna nie jest jednorodna. Można wyróżnić w niej powierzchnię oraz głębię. Powierzchnię wewnętrznej przestrzeni „zamieszkują” przeżycia mocno naznaczone znaczeniem, charakterem i kolejnością (rola czasu) wydarzeń, które je wywołały. Dlatego właśnie Tischner mówi, że powierzchniowe "przeżycia układają się jedno-obok-drugiego" ${ }^{58}$, jakby odbijając wydarzenia, które je wywołały.

Sytuacja wygląda inaczej $\mathrm{z}$ dala od powierzchni. Im bliżej głębi, tym przeżycie staje się mocniej zabarwione swojością człowieka i tym mniejsze znaczenie ma czas jego zaistnienia. Zatem odnośnie do istoty głębi wewnętrznej Tischner nie zgadza się ani z propozycją Kanta (kategorie czasu jako porządkujące wnętrze), ani z podejściem psychologii asocjacjonizmu (wnętrze składa się z odseparowanych elementów składowych).

Według Maxa Schelera różne wartości mają różną wagę. Są wartości wyższe i są wartości niższe ${ }^{59}$. Józef Tischner, powołując się na przekonanie Schelera, iż „im wyższa wartość [...] tym w głębszy sposób jest odczuwana"60, twierdzi, że ludzka swojość to nie tylko to, co najbardziej oswojone, ale też to, co najbardziej cenne. Te najcenniejsze wartości budują centrum człowieka. Ich charakter w najmocniejszy sposób wpływa na strukturę agatologicznej przestrzeni świadomości. Udzielając wywiadu (a więc musząc mówić w sposób skrótowy i obrazowy) Jarosławowi Gowinowi i Dorocie Zańko, Józef Tischner przyrównał ludzkie wnętrze

57 H. Bergson, O bezpośrednich danych świadomości, tłum. K. Bobrowska, Warszawa 1913, s. 115 (Tischner fragment ten, w swoim tłumaczeniu, przytacza w Świecie ludzkiej nadziei, Kraków 1994, s. 110-111).

58 J. Tischner, Spór o istnienie człowieka, dz. cyt., s. 277.

59 Scheler pisze na przykład: „to, że jakaś wartość jest «wyższa» od innej wartości, uchwytuje się w pewnym szczególnym akcie poznawania wartości, który nazywa się "preferowaniem»” (M. Scheler, Materialne a priori w etyce, przeł. A. Węgrzecki, „Znak” (1967) nr 12, s. 1518).

60 J. Tischner, Spór o istnienie człowieka, dz. cyt., s. 312. 
do jaskini. Powiedział „dusza jest rozległą jaskinią [...], jest przestrzenią, która wyłapuje głos Boga i zamienia go w echo"61.

$\mathrm{W}$ tej wypowiedzi Tischner potwierdza wypowiedziane wcześniej przekonanie o przestrzennym charakterze wnętrza człowieka oraz zwraca też uwagę na jego związki ze światem. Zwrot „głos Boga” można oczywiście potraktować tylko jako poetycką metaforę. Ale można też uznać go za wskazanie na to, że uhierarchizowanie zamieszkujących to wnętrze wartości tworzy dobro człowieka. Dobro to, jak każde dobro prawdziwe, ma udział w boskim dobru. Należy wszakże pamiętać, iż według Tischnera Bóg nie mówi wprost, ale poprzez twarz człowieka w biedzie. Twarz innego jest śladem nieskończonego. Filozof pisał gdzie indziej: „Bóg nie nakazuje inaczej, jak przez ludzi, dla których trzeba działać"62.

Przestrzeń wewnętrzną tworzą wartości będące efektem aktywności człowieka w świecie. Ich aksjologiczna „waga” jest różna. W związku z tym, wnętrze które one „zasiedlają”, nie ma charakteru izomorficznego (ani tym bardziej punktowego). Jego struktura jest zróżnicowana.

Według myśliciela te wartości, które są związane ze spotkaniami z innymi ludźmi, najmocniej znaczą ludzkie wnętrze ${ }^{63}$. Wartość powstała w wyniku najbardziej znaczącego spotkania (lub kilku spotkań) wyznacza w największej mierze charakter wnętrza "tego, kto spotyka"64. Do tej podstawowej wartości „dobudowywują się" inne, mniej znaczące wartości. Obrazowo można też powiedzieć, że „barwa” przestrzeni wewnętrznej jest w największym stopniu określana przez „barwę” najważniejszej wartości. Inne wartości „obecne” w tej przestrzeni, ten „podstawowy kolor" jedynie dopełniają. Zestrojone według takiego porządku, wartości

61 J. Tischner, D. Zańko, J. Gowin, Przekonać Pana Boga, Kraków 1999, s. 93.

62 J. Tischner, Filozofia dramatu, dz. cyt., s. 43.

63 Podobnie zdaje się uważać Lévinas. Pisze na przykład: „Sobość jest samym wydarzeniem otwarcia się na innego, występowania w bierniku, dźwigania na sobie innych; wydarzeniem będącym przeciwieństwem pewności Ja, które jako wolne powraca do samego siebie" (E. Lévinas, Inaczej niż być lub ponad istotą, tłum. P. Mrówczyński, Warszawa 2000, s. 200).

64 J. Tischner, Filozofia dramatu, dz. cyt., s. 60. Jeśli to wnętrze już wcześniej było jakoś dookreślone, to ta nowo zaistniała wartość sprawia, że zmienia ono (tj. to wnętrze) swój charakter (zob. J. Tischner, Spór o istnienie człowieka, dz. cyt., s. 315). 
tworzą hierarchiczną strukturę tej przestrzeni. Ona stanowi dobro osoby. $\mathrm{Z}$ nim człowiek się utożsamia i je kocha.

\section{Wolność według Józefa Tischnera}

Dopiero rozpoznanie wnętrza człowieka pozwala zrozumiale podejść do opisu sposobu rozumienia wolności przez Józefa Tischnera. Według niego nie da się zrozumieć ludzkiej wolności ani na gruncie ontologii, ani na gruncie epistemologii. Posługiwanie się takimi kategoriami, jak siła, przyczyna, skutek sugeruje, że bardziej wolnym jest ten, kto ma więcej siły, by swoją wolę przeprowadzić. Wolność wiązałaby się tu z możnością potwierdzania siebie w tym, co inne ${ }^{65}$. Nie tak rozumie wolność Tischner. Jego zdaniem stosowanie takiej zasady w praktyce dość szybko doprowadziłoby do zaprzeczenia idei wolności. Do bycia wolnym nie wystarcza też wiedza i rozumienie rzeczywistości. Wolność nie jest też tylko aktem rozumu.

Należy też dodać, że wolność, jaką opisuje Tischner, nie ma charakteru postulatywnego. To znaczy nie chodzi mu o prawo do wolności - za nim opowiada się na przykład uchwalona w 1948 roku w Paryżu Powszechna Deklaracja Praw Człowieka - lecz o wolność samą. Prawo do wolności to uprawnienie do niezależnego, niewymuszanego oraz zapodmiotowanego działania człowieka. Prawo to gwarantuje, albo powinna gwarantować, wspólnota ${ }^{66}$. Tischnerowi natomiast zale-

65 Tak jest na przykład według Kartezjusza, który pisał, że wolność polega „na tym, że możemy to samo uczynić albo tego nie uczynić (tzn. potwierdzić lub zaprzeczyć, pójść za czymś lub unikać tego), albo raczej na tym, że przystępujemy do potwierdzenia lub zaprzeczenia tego, czyli podążania za tym lub unikania tego, co nam intelekt przedkłada, w ten sposób, że czujemy przy tym, iż żadna siła zewnętrzna nas do tego nie zmusza" (R. Descartes, Medytacje o pierwszej filozofii, tłum. M. i K. Ajdukiewiczowie, Warszawa 1958, s. 6).

${ }^{66}$ Wielu, w przekonaniu, że człowiek ma niepodważalne „prawo do wolności”, wyraża to stwierdzeniem „człowiek jest wolny”. To są jednak dwa różne zagadnienia. Zwracał na to też uwagę Isaiah Berlin w swoim słynnym eseju z 1958 roku pt. Dwie koncepcje wolności, tłum. D. Grinberg, Warszawa 1991, s. 108-192. Warto też zauważyć, że żadna wspólnota nie dopuszcza sytuacji, by jej członkowie mieli absolutną swobodę. W imię trwania wspólnoty jako wspólnoty potrzebne są pewne ograniczenia. One nadają wspólnocie określony kształt. Te ograniczenia dotyczą bardzo wielu obszarów, 
ży na rozpoznaniu, jaka jest natura tej wolności, którą faktycznie żyje człowiek. Według niego ludzka wolność nie jest inną nazwą na przypadkowość lub nieprzewidywalność. „Z tego, że pewnych wydarzeń przewidzieć nie można, nie wynika, że one są «wolne»; wolność i przypadkowość to dwie różne sprawy"67.

Tischner jest przekonany, że badając wolność człowieka, należy pamiętać, iż oddziałuje ona nie tylko na to, co inne, co na zewnątrz, ale także wpływa na samego działającego, dookreślając go. Dlatego uważa, że wolność to „przede wszystkim problem działania «do wnętrza» i «robienia $\mathrm{z}$ samym sobą» czegoś, co wydaje się niemożliwe" ${ }^{\text {"68 }}$. Określenie „niemożliwe” dotyczy sytuacji oglądu człowieka z perspektywy zewnętrznej. Z niej niemożliwe wydaje się to, że człowiek $\mathrm{z}$ własnej woli rezygnuje z bycia tym, kim był do tej pory. Tischner pyta: „Jak to możliwe, by byt, który «jako byt», jest tożsamy ze sobą, «rezygnuje» ze zdobytej już tożsamości na rzecz «rozszczepienia» i mirażu innej tożsamości?" 69.

Inspiracji do znalezienia odpowiedzi na to pytanie dostarczyła autorowi Świata ludzkiej nadziei filozofia Jeana-Paula Sartre'a ${ }^{70}$. Dla tego francuskiego egzystencjalisty bycie sobą jest możliwe tylko wówczas, gdy człowiek wybiera wolność w imię bycia sobą, czyli wolnością. Bycie wolnym jest dla Sartre’a podstawą człowieczeństwa.

Sartre (podobnie jak Tischner) staje w opozycji do Tomasza z Akwinu, dla którego wolność jest tylko jedną z władz pożądawczych człowieka. Według średniowiecznego filozofa człowiek jest bytem posiadającym wolę, której przysługuje cecha wolności. A ta z natury kieruje się ku temu, co dobre. Jean-Paul Sartre uważa inaczej: człowiek nie tyle ma wolność, ile jest wolnością. Gdy rezygnuje z wolności, znika jako

począwszy od rozumienia, kim jest inny człowiek, charakteru relacji międzyludzkich, struktury i sposobu wyłaniania władzy, a skończywszy na określeniu relacji do świata natury.

${ }_{67}$ J. Tischner, Spór o istnienie człowieka, dz. cyt., s. 309.

68 J. Tischner, Spór o istnienie człowieka, dz. cyt., s. 295.

69 J. Tischner, Spór o istnienie człowieka, dz. cyt., s. 295.

70 Kilkukrotnie podejmowano już próby wskazania na filozofie, które były inspiracją dla Tischnera (na przykład w książce Pytając o człowieka - myśl filozoficzna Józefa Tischnera, red. W. Zuziak, Kraków 2002). Wymieniano Hegla, Heideggera, Lévinasa, Kierkegaarda, Schelera. Nikt jednak do tej pory nie zajął się zbadaniem wpływu filozofii Sartre’a na myśli Tischnera. 
człowiek. Przestaje być bytem-dla-siebie i staje się bytem-w-sobie. „Byt, który jest tym, czym jest, nie może być wolny"71. Dla Sartre’a jednak wolność to źródło negacji. Być wolnym to móc w każdej chwili zrobić coś nowego. Porzucić siebie, jakim się było, i wybrać siebie jako kogoś innego, nowego ${ }^{72}$.

Być wolnym to znaczy móc wybierać z siebie jako czystej wolności, czyli całkowitej nowości. $\mathrm{Z}$ tego, czego jeszcze nie ma ${ }^{73}$. Byt jest. W takim razie bycie wolnym związane jest $\mathrm{z}$ wybieraniem $\mathrm{z}$ czegoś, czego nie ma, czyli z niebytu. $Z$ takiego rozumowania, według Tischnera, bierze początek myślenie o wolności jako negatywności.

Dla polskiego filozofa twórczy aspekt wolności człowieka jest niezwykle ważny. Nie uważa on jednak, by bycie wolnym związane było z nicościowaniem człowieka. Nie zgadza się też z konsekwencjami takiego rozumienia wolności, w ramach którego człowiek w imię wolności musi zanegować siebie. Uważa że, człowiek wybiera nie dla samego aktu wyboru, lecz by coś zrealizować. Żyjąc, a więc wybierając, chodzi nam zawsze o $\cos ^{74}$.

Zrozumienie i przekroczenie tej aporii nie jest możliwe na gruncie myślenia w żywiole ontologii, gdzie trzeba wybrać między dwoma skrajnymi opcjami, między bytem i brakiem bytu. Lepsze możliwości zrozumienia złożoności wolności daje przejście na grunt agatologii.

Jej badanie przez Tischnera opiera się na konstatacji, iż wolność - choć jest „poza bytem i niebytem”75 - nie jest czymś odrywającym od rzeczy-

71 J.-P. Sartre, Byt i nicość, tłum. J. Kiełbasa i in., Kraków 2007, s. 542.

72 Dla niego „wolność to nicość, która jest zaistniała w samym wnętrzu człowieka, przymuszająca rzeczywistość-ludzką do tego, by tworzyła samą siebie, miast po prostu byç" (J.-P. Sartre, Byt i nicość, dz. cyt., s. 542).

73 Bowiem „dla rzeczywistości-ludzkiej być to wybierać siebie: ani z zewnątrz, ani od wewnątrz nie przychodzi do niej nic, co mogłaby otrzymać lub przyjąć” (J.-P. Sartre, Byt i nicość, dz. cyt., s. 542), podobnie Hegel: „Wolność jest sama w sobie negatywnością i jako taka musi przed nami wystąpić” (G. Hegel, Fenomenologia ducha, tłum. A. Landmann, Warszawa 1964, s. 234).

${ }^{74}$ Tischner już w latach 70. zauważał, że „Nie wybieramy, aby wybierać. Wybieramy, aby coś wcielać w życie, a tym, co wcielamy w życie, jest zawsze jakaś wartość” (J. Tischner, Świat ludzkiej nadziei, dz. cyt., s. 157).

75 J. Tischner, Spór o istnienie człowieka, dz. cyt., s. 298. 
wistości, czyli także od własnej przeszłości. Istotne jest też według niego to, że działa ona w dwóch kierunkach. Ma tu na myśli to, iż jej aktywność realizuje się na dwóch obszarach. Działa na świat i działa na samego działającego. W aspekcie zewnętrznym wpływa na otoczenie, zmienia je, działając z mocą, "jak to, co jest "wyżej», działa na to, co jest "niżej»"76. W aspekcie wewnętrznym działa na samego działającego, dookreślając go do dobra albo do zła.

Przeprowadzona w tym tekście rekonstrukcja Tischnerowskiej koncepcji wnętrza osoby pokazała, że nie jest ono "puste” albo - mówiąc językiem Locke’a - „punktowe”. Zamieszkują je wartości. Są one różnej wagi, jedne są bardziej, inne mniej cenne. Wartości te razem tworzą pewną (zawsze konkretną, związaną z konkretnym człowiekiem) strukturę, na której kształt (albo lepiej - barwę) decydujący wpływ mają te $\mathrm{z}$ nich, które są dla tej osoby cenniejsze. Wszystkie one, choć w różnym stopniu, budują dobro osoby.

Poprzez świadomość tego dobra człowiek siebie pojmuje. Jest tym, co ma. A ma przede wszystkim to, co uważa za dobre. Według Tischnera bowiem „idea świadomości wiąże się w sposób szczególny z ideą dobra"77. Opisana w ten sposób rzeczywistość wnętrza osoby jest przez myśliciela określana jako agatologiczna przestrzeń świadomości.

Wolność wyraża i realizuje się poprzez wybory. W tekstach Tischnera możemy znaleźć opisy dwóch typów wyborów. Z perspektywy badacza (bo człowiek uczestnicząc w życiu, nie wie, w jaką sytuację aktualnie „wchodzi”) pierwszy typ określić można jako stabilnie-rozwijający, a drugi jako rewolucyjny (niestabilny).

Chcąc przybliżyć pierwszy typ wyborów, należy zauważyć, że badanie przestrzeni wewnętrznej człowieka (inaczej niż badanie sfery działań zewnętrznych) doprowadza do odkrycia, iż wybór nie jest aktem ekspresji o niejasnych korzeniach, lecz jest powiązany $\mathrm{z}$ agatologią osoby. Wychodząc ku światu, żyjąc, działając, spośród możliwych do zrealizowania wartości osoba wybiera te, które są w zgodzie z charakterem jej

76 J. Tischner, Spór o istnienie człowieka, dz. cyt., s. 298.

77 J. Tischner, Spór o istnienie człowieka, dz. cyt., s. 287. 
agatologicznej przestrzeni świadomości. Ich zrealizowanie powoduje „bycie bardziej” sobą. Sobośćc ${ }^{78}$ jest bardziej sobą, im bardziej wybiera siebie $^{79}$.

Wybór takiej, a nie innej wartości do realizacji nie jest arbitralną, do niczego nieodwołującą się decyzją. Sposób jej powiązania z człowiekiem najlepiej zaobserwować, przyglądając się jego wnętrzu. Wybierając, człowiek przedkłada w realizacji tę wartość, która jest mu bliższa, nad tą, która jest mu dalsza. Wybierane jest takie działanie, którego realizacja wytworzy wartość będącą w dużej zgodności z dobrem budującym wnętrze wybierającego. Tischner posługuje się tu terminem „przyswajanie”. „Przyswojenie jest «aktem», który pojawia się w porządku agatologicznym" ${ }^{80}$.

W rezultacie przyswojenia wartości „pokrewnej” wartościom fundującym wnętrze człowieka coś się zmienia ${ }^{81}$. Ma miejsce modyfikacja (albo można rzec wzbogacenie) „barwy” dobra wewnętrznego. Wyłania się też nowy, bo zmodyfikowany, kształt wolności. Tischner opisuje to w następujący sposób: „Wolność wchodzi w intymny związek z przeżyciami, szczególnie z przeżyciami aksjologicznymi, i dzięki nim rysuje sobie przestrzeń preferencyjną, w której możliwe jest przedkładanie jednego $\mathrm{z}$ pominięciem drugiego" ${ }^{82}$.

Jedną z podstawowych tez filozofii człowieka Tischnera jest przekonanie, że „wolność [...] to sposób istnienia dobra" ${ }^{83}$. Oznacza to, że

78 „Sobość jest «mieniem». «Mienie» w osobie jest bardziej podstawowe niż byt. Sobość dojrzewa, «dojrzewając w mieniu» (J. Tichner, Spór o istnienie człowieka, dz. cyt., s. 332). Widać, że Tischner uznał, iż termin „sobość”, nawiązujący do angielskiego self, bardziej jest zgodny z jego rozumieniem człowieka autentycznego, niż terminy zwykle używane w polskiej literaturze, takie jak na przykład jaźń czy podmiot.

79 Podobnie widział tę sytuację Bergson. „W istocie, wolne postanowienie jest wypływem całej naszej duszy; a akt będzie tym wolniejszy, im bardziej serja dynamiczna, z którą się wiąże, utożsamia się z naszym ja podstawowym" (H. Bergson, O bezpośrednich danych świadomości, dz. cyt., s. 117).

80 J. Tischner, Spór o istnienie człowieka, dz. cyt., s. 305.

81 „Nie można wskazać żadnego momentu, od którego zaczęło się «przyswajanie». A jednak nie jest ono «odwieczne», nie jest «synchroniczne» z istnieniem Ja" (J. Tischner, Spór o istnienie człowieka, dz. cyt., s. 255).

82 J. Tischner, Spór o istnienie człowieka, dz. cyt., s. 299.

83 J. Tischner, Spowiedź rewolucjonisty, Kraków 1993, s. 35. 
kształt dobra osoby wyznacza kształt jej wolności. W rezultacie przyswojenia nowej wartości osoba w nowy, zmodyfikowany sposób „wychodzi” ku światu ${ }^{84}$. I gdy pojawia się następna nowa sytuacja i nowe wyzwanie, $\mathrm{w}$ ten nieco zmodyfikowany sposób, problem ten stara się rozwiązać. Tischner zauważa też, że wolność jako sposób budowania dobra poprzez realizację właściwych sobie wartości „wypracowuje” z czasem pewne sposoby, można rzec schematy działania. Określa je jako „struktury przestrzeni dramatycznej"85.

Inny jest klucz do zrozumienia sposobu wybierania, który określiłem jako rewolucyjny. Zapoczątkowywany on jest nie przez osiągnięcie jakiejś dojrzałości duchowej albo intelektualnej (co było bliskie Platonowi), ale przez zewnętrzne wydarzenie. Człowiek realizuje swoją wolność w zgodzie ze swoim dobrem wewnętrznym aż do chwili, gdy zaistnieje coś, co chwieje jego dotychczasowym sposobem rozumienia dobra. Tischner wskazuje tu na sytuację spotkania z człowiekiem dotkniętym nieszczęściem (wdowa, sierota) lub wystawionym na działanie od-ludzkiego zła (Chrystus prześladowany przez Szawła) ${ }^{86}$. Moment w którym Spotykający odkrywa, że Spotkany jest zagrożony, jest przełomowy. Zabiedzona (ewentualnie zalękniona) twarz „nie pozwala” mu przejść obojętnie. Konstatuje, że „tak dalej być nie może”. Poruszenie, albo mocniej wstrząs, jakiego doznał Spotykający, są tak dojmujące, że pojawia się bunt, który szybko przekształca się w niezgodę na taką sytuację. Zaraz potem potrzeba udzielenia pomocy drugiemu zaczyna jawić się jako ważniejsza niż potrzeba kontynuowania aktualnie realizowanego sposobu bycia. Nie "takiego sobie" sposobu bycia - dodajmy, ale wynikającego $\mathrm{z}$ dotychczasowego rozumienia dobra i powiązanej z nim wolności.

Czy to znaczy, że według Tischnera - w imię pomocy potrzebującemu - należy poświęcić swoją wolność? Ważny dla filozofa myśliciel, Emmanuel Lévinas, jest przekonany o prymacie odpowiedzialności

84 „Wolność, która wybiera, przyswaja nie tylko to, co wybiera, ale przyswaja określoną postać, określoną formę wolności” (J. Tischner, Spór o istnienie człowieka, dz. cyt., s. 306).

85 J. Tischner, Spór o istnienie człowieka, dz. cyt., s. 299.

${ }^{86}$ Dla Tischnera, inaczej niż dla Sartre’a, inni nie są piekłem, lecz wyzwaniem. W pierwszej kolejności wyzwaniem jest człowiek biedny, zagubiony, samotny. 
w stosunku do wolności. „Odpowiedzialność za drugiego człowieka, która nie jest akcydensem przydarzającym się Podmiotowi, lecz poprzedza w nim Istotę, nie czekała na wolność, dzięki której zostałoby podjęte zaangażowanie wobec drugiego człowieka" ${ }^{87}$. Tischner $\mathrm{z}$ tym stwierdzeniem zgadza się i nie zgadza ${ }^{88}$. Zgadza się w tym sensie, że uważa, iż w tym wypadku odpowiedzialność za będącego w trudnym położeniu człowieka jest ważniejsza niż wolność Spotykającego. Ale należy dodać, że chodzi tu o wolność aktualnie realizowaną.

$\mathrm{Z}$ tym ostatnim stwierdzeniem wiąże się wspomniana niezgoda. $\mathrm{Au}-$ tor Filozofii dramatu uważa, że wobec spotkania cierpiącego i zagubionego człowieka trwanie przy dotychczasowym sposobie bycia byłoby już nie realizacją wolności, lecz zniewoleniem. Byłoby bowiem zamknięciem się w tym, co - w świetle dziejącego się właśnie spotkania - okazuje się dobrem niepełnym albo nawet fałszywym. W spotkaniu bowiem chodzi o dobro. To ono stanowi fundament człowieczeństwa. I za nie człowiek jest odpowiedzialny.

Spotykający odkrywa, że dobro prawdziwsze (jestem świadom ułomności tego sformułowania, ale nie znajduję lepszego) jest zagrożone. Konstatuje też, że dotychczasowe rozumienie dobra było niepełne. Według Józefa Tischnera bowiem dobro nigdy nie jest dane człowiekowi w pełni. Życie jest sztuką celnych odsłonięć dobra ${ }^{89}$. Przewodnikiem w drodze od dobra do dobra jest drugi, najczęściej ten, w którym to dobro jest zagrożone.

Jeśli Spotykający decyduje się pomóc Drugiemu i rzeczywiście to czyni, to mają miejsce dwie zmiany. Po pierwsze ma miejsce zmiana sytuacji egzystencjalnej Drugiego i po drugie - na bazie tego wydarzenia powstaje wartość. Ona wzbogaca też samego Pomagającego. Jej „waga” jest tak poważna (wszak podważyła dotychczasową aksjologię Pomagającego),

87 E. Lévinas, Inaczej niż być lub ponad istotą, dz. cyt., s. 192.

88 Por. A. Hernas, Tischner i Lévinas. Księdza z rabinem spór o człowieka, „Logos i Ethos” (2004) nr 2, s. 224-236.

${ }^{89}$ Pisałem o tym szerzej w eseju o sztuce etyki, zob. Z. Dymarski, The art of ethics as the art of wise life in the concept of Józef Tischner, "Studies in East European Thought" (2019) no 71, s. 375385; doi.org/10.1007/s11212-019-09339-0. 
że gdy „wchodzi do wnętrza” Pomagającego nie "godzi się" na przyswojenie do istniejącego już zestawu wartości, ale je kwestionuje i zmienia. $\mathrm{W}$ rezultacie znajdujące się $\mathrm{w}$ nim (tj. tym wnętrzu) wartości są porządkowane na nowo. Jedne wartości zyskują na znaczeniu, inne tracą. Dotychczasowy układ wartości zostaje zatem zastąpiony nowym ${ }^{90}$. On tworzy nowe dobro. „Dobro «rodzi się» w wyniku splotu warunków zewnętrznych i wewnętrznych" ". Ono też nadaje nowy kształt wolności Spotykającego. „Wolność abstrakcyjna, wydzielona z dramatu, «Wolność jako wolność», istnieje tylko na papierze" ${ }^{\text {" }}$.

Życie człowieka nie jest jednostajną, spokojną egzystencją. Jest gubieniem się i odnajdywaniem. Jest zawierzaniem i rozczarowywaniem się. Jest pełnym trudów i potknięć poszukiwaniem. „Osoba, która «idzie przez świat», «idzie» od zwierzenia do zwierzenia i od zawierzenia do powierzenia siebie" 93 .

$\mathrm{Na}$ drodze do budowania swojego prawdziwego dobra człowiek doświadcza również spotkań ze złymi ludźmi. Zdarza się tak, że ten spotkany tylko udaje człowieka pokrzywdzonego albo nawet przyjacielskiego, a tak naprawdę jest zło-czyńcą. W spotkaniu przybiera maskę ludzkiej biedy lub utrudzonego wędrowca, gdy tymczasem jest kimś innym. Tischner w swoich pracach poświęca wiele miejsca charakterystyce sposobów, w jakich zło czyniący człowiek zdąża do zapanowania nad drugim człowiekiem. Odwołując się do przykładów postaci wziętych z dramatów Szekspira, wyjaśnia, jak działa pokusa, groźba i zdrada. Jego zdaniem ludziom, którzy się nimi posługują, w pierwszej kolejności chodzi nie tyle o zmuszenie drugiego człowieka do jakichś działań, ile o skłonienie, by zaakceptował to, co zło-czyńca mu oferuje. Czyli by mu uwierzył, uznał

90 „Im głębiej wchodzimy w subiektywność, tym wyraźniej ukazuje się nam zamieszkujący ją inny" (J. Tischner, Spór o istnienie człowieka, dz. cyt., s. 252). To znaczy, że człowiek jako człowiek nie jest sam z siebie. Na to, jaki jest, wpływ mają inni. I dlatego Tischner dopowiada: „Subiektywność jest tym szczególnym «miejscem», w którym przejawia się gra Dobra z samym sobą" (J. Tischner, Spór o istnienie człowieka, dz. cyt., s. 253).

91 J. Tischner, Spór o istnienie człowieka, dz. cyt., s. 200.

92 J. Tischner, Spór o istnienie człowieka, dz. cyt., s. 299.

93 J. Tischner, Spór o istnienie człowieka, dz. cyt., s. 187. 
oferowane wartości za cenne oraz prawdziwe i zaczął według nich żyć. Tym samym by przebudował własne wnętrze i - co za tym idzie - stał się następnym orędownikiem i rzecznikiem (w słowie i w czynie) sprawy zła.

Według Józefa Tischnera zaangażowanie w sprawę zła jest stopniowalne. Filozof wyróżnia dwa (a przy pewnej interpretacji i trzy) możliwe poziomy zaangażowania w zło (bo trudno tu mówić o bliskości i przyjaźni). Można je określić jako stadium odwetu, stadium demonizujące i stadium demona ${ }^{94}$.

W pierwszym przypadku chodzi o to, że człowiek doznawszy poniżenia, oszustwa lub zdrady, doznaje poczucia krzywdy. Jest przekonany, że panująca w świecie równowaga została naruszona i on musi podjąć działania, by ją przywrócić. Według Tischnera taki człowiek nie jest doszczętnie zły. Chce bowiem zadawać zło w imię swoiście pojętej sprawiedliwości, a nie dla samego zła. „Odwet wyłania się z ogólnej «złości na świat»"

Drugi przypadek wiąże się z zaprzedaniem się złu. W tym stadium człowiek zyskuje przekonanie, że zło jest zasadą świata, a dobro ma wobec niego pełnić służebną rolę. Jest po to, by zło miało czym się „karmić”. Tutaj odmawia się racji Augustynowi głoszącemu, że wszystko jest dobre, a zło wynika tylko z chwilowego braku dobra. Dlatego charakteryzując to stadium, Tischner pisze, że ma tu miejsce manichejskie rozumienie rzeczywistości. I wyjaśnia, że rozumie ją jako „radykalne odwrócenie sensu wiążącego dobro i zło, możliwe do wyobrażenia jedynie na płaszczyźnie ludzkiego dramatu"96. W świecie, w którym zasadą rzeczywistości jest zło, racjonalny jest ten, kto zło czyni, a irracjonalny, kto się tej zasadzie sprzeciwia. W imię takiego porządku człowiek staje się szantażystą, kusicielem, nienawistnikiem, kłamcą, zdrajcą... Dyskusyjne jest to, czy taki osobnik zasługuje jeszcze na miano człowieka. Tischner kogoś takiego określa terminem „człowiek pozorny”97.

94 Kategorie te omawiam tu bardzo skrótowo. Piszę o nich szerzej w artykule Człowiek w horyzoncie rozpaczy, w: Wobec Dobra i Prawdy w dialogu z Tischnerem, red. A. Bobko, M. Karolczak, Kraków 2013, s. 220-241.

95 J. Tischner, Spór o istnienie człowieka, dz. cyt., s. 98.

96 J. Tischner, Spór o istnienie człowieka, dz. cyt., s. 14-15.

97 J. Tischner, Spór o istnienie człowieka, dz. cyt., s. 17. 
On również staje się kolejnym ogniwem wielkiego łańcucha zło-czyńców i podejmuje działania mające na celu przeciągnięcie innych na stronę zła. Przepełniony złem, nie szanuje ani dobra, ani wolności drugiego. Chce go zmusić do uległości, do przyjęcia tego, co ten mu oferuje. Józef Tischner zauważa też, że zło przychodzące pod postacią groźby, pokusy lub zdrady nie prosi ani nie przekonuje. Nie buduje przestrzeni wyboru, mówiąc na przykład: „możesz to wybrać, ale nie musisz”. Chce drugiego przymusić do uległości, perswaduje, nakazuje, grozi, oszukuje i nie stwarza możliwości odmowy. Często, posługując się groźbą, szantażuje: "zabiję cię, chyba, że postąpisz tak, jak ci nakazuję" ${ }^{98}$. Z dobrem jest inaczej. Nie ma dobra poza wolnością. Sytuacja wyjściowa człowieka nie jest „czysta”. Na świat „przychodzi jako wielorako zniewolony”9. Bycie dobrym to zadanie, a nie stan faktyczny. Tischner wiąże je z poszukiwaniem takiego dobra, które jest najprawdziwsze, dla którego warto $\dot{z} y c ́^{100}$. „Człowiek nie jest z natury taki, jako być powinien; dopiero drogą przeobrażenia dochodzi do prawdy"101.

Idąc po wyboistej drodze, człowiek buduje swoje wewnętrzne dobro. Jego kształt w ciągu życia ulega przemianom. Tischner jest przekonany, że człowiek szuka siebie. Sobość wiąże z dobrem. Chce dobra, by stało się jego dobrem. „Sobość jest «mieniem». «Mienie» w osobie jest bardziej podstawowe niż byt. Sobość dojrzewa, «dojrzewając w mieniu»" ${ }^{102}$. $\mathrm{W}$ pewnym sensie przewodnikami w zdążaniu do autentyczności są spotykani ludzie ${ }^{103}$. To oni „mają umiejętność" naprowadzania spotykanych na dobro. Ze względu na sytuację początkową (sytuację niedoskonałości) człowieka i skokowo-dialektyczny charakter zbliżania się

98 J. Tischner, Filozofia dramatu, dz. cyt., s. 158.

99 J. Tischner, D. Zańko, J. Gowin, Przekonać Pana Boga, dz. cyt., s. 161.

100 Tischner szkicuje też możliwość spojrzenia na dzianie się człowieka od strony absolutu tożsamego z Dobrem. Z takiej perspektywy ludzkie podążanie za dobrem jawi się jako stopniowe przedzieranie się z półmroku ku światłu. Źródło światła, choć samo niewidoczne, umożliwia widzenie. Jednak opis tej strony wymagałby osobnego tekstu, więc tu się zatrzymuję.

101 J. Tischner, Spór o istnienie człowieka, dz. cyt., s. 169.

102 J. Tischner, Spór o istnienie człowieka, dz. cyt., s. 332.

103 „Dobro «rodzi się» jako owoc «zapłodnienia», które przychodzi z zewnątrz” (J. Tischner, Spór o istnienie człowieka, dz. cyt.). 
do dobra Tischner uważa, że raczej powinniśmy mówić o wyzwalaniu niż o wolności. „Wolność jest człowiekowi dana jako wyzwolenie, czyli droga do wolności"104.

Czyniąc zło, człowiek nie posiada siebie, bo jest na służbie u zła. W konsekwencji to ono nim włada, a nie on. Dlatego właśnie Tischner uważa, że człowiek posiada siebie dopiero wówczas, gdy rezygnuje z posiadania innego. Pozwalając innemu być (w szerokim tego słowa znaczeniu), doświadcza własnej wolności. A to oznacza, że może głębiej być sobą.

\section{Myśli podsumowujące}

Rozstrzygnięcie, naszkicowanej w tym tekście, możliwej konfrontacji paradygmatu liberalnego i chrześcijańskiego w kwestii wolności wydaje się niezwykle ważne dla zrozumienia intelektualnej i duchowej sytuacji współczesnego świata. Szkoda, że do tej konfrontacji nie doszło. Trudno podsumowywać spór, który, mimo możliwości zaistnienia, nie zaistniał. Trudno przewidzieć, w którą stronę by się potoczył.

Stanowiska wyjściowe zostały zarysowane, więc sformułuję kilka myśli w odwołaniu do nich. Na pewno zarówno Tischner, jak i Kołakowski zgodziłby się co do kilku kwestii. Najważniejszą z nich byłoby obopólne przekonanie o szczególnym stanowisku człowieka w kosmosie. Żaden z filozofów nie separowałby go (tj. człowieka) od otoczenia, jak na przykład czynił to Kartezjusz. Podkreślaliby też wagę otoczenia dla dookreślenia tego, kim człowiek jest. Zapewne zgodnie opowiedzieliby się też za tezą, że wolność jest fundamentem człowieczeństwa.

Przedmiotem sporu byłaby natomiast natura wolności i jej związki z dobrem i złem. Trudne, ale na pewno bardzo inspirujące byłyby ich polemiki w kwestii wpływu ludzkich wyborów na kształt ludzkiej wolności. Dyskutując tę kwestię, na pewno musieliby skonfrontować się z poglądami Augustyna, który sądził, że gdy człowiek kieruje się własną 
wolą, kieruje się na siebie i wówczas wybiera źle. Dlatego winien swoją wolę podporządkować woli Boga, a wówczas naprawdę będzie wolny ${ }^{105}$.

Być może spór ten byłby też okazją do tego, by Kołakowski wyjaśnił, jak się ma, głoszone przez niego w wielu tekstach, przekonanie, że człowiek jest wolny, niezależnie czy wybiera dobro czy zło, do poglądu, $\mathrm{z}$ omawianego $\mathrm{w}$ tym tekście eseju o wychowaniu, gdzie stwierdził, że nienawiść oślepia i ubezwłasnowolnia człowieka. Należy żałować, że do polemiki Kołakowskiego i Tischnera w kwestii wolności nie doszło.

\section{Bibliografia}

Augustyn, $O$ wolnej woli, tłum. A. Trombala, w: Augustyn, Dialogi filozoficzne, Kraków 1999, s. 493-649.

Augustyn, Wyznania, tłum. Zygmunt Kubiak, Kraków 1994.

Bergson H., O bezpośrednich danych świadomości, tłum. K. Bobrowska, Warszawa 1913.

Berlin I., Two Concepts of Freedom, w: I. Berlin, Liberty, Oxford 2002, s. 166-217.

Chudoba W., Leszek Kołakowski: kronika życia i dzieła, Warszawa 2014.

Dąbrowski S., Polemika Józefa Tischnera z tradycją tomistyczna jako spór o kształt wspótczesnej edukacji religijnej w Polsce, „Forum Pedagogiczne” (2019) nr 2, s. 93-105.

Descartes R., Medytacje o pierwszej filozofii, tłum. M. i K. Ajdukiewiczowie, Warszawa 1958.

Dymarski Z., The art of ethics as the art of wise life in the concept of Józef Tischner, „Studies in East European Thought" 71 (2019) Issue 4, s. 375-385; doi.org/10.1007/s11212019-09339-0.

Dymarski Z., Człowiek jako rozumna wolność. Droga Leszka Kołakowskiego do filozofii człowieka, w: Rozum i przestrzenie racjonalności, red. A. Chmielecki, Gdańsk 2010, s. 81-98.

Dymarski Z., Człowiek w horyzoncie rozpaczy, w: Wobec Dobra i Prawdy w dialogu $z$ Tischnerem, red. A. Bobko, M. Karolczak, Kraków 2013, s. 220-241.

105 Augustyn pisał, że „nasza wolność to uległość wobec tej najwyższej prawdy” (Augustyn, O wolnej woli, w: Augustyn, Dialogi filozoficzne, tłum. A. Trombala, Kraków 1999, s. 563). 
Dymarski Z., Debata księdza Józefa Tischnera ze szkołą lubelską, „Logos i Ethos” (1998) nr 1, s. 235-245.

Dymarski Z., Gdzie jest zło? Rola religii w lokalizacji zła w ujęciu Leszka Kołakowskiego i Józefa Tischnera, „Humaniora” (2017) nr 2, s. 47-61.

Dymarski Z., Józef Tischner wobec marksizmu. Wstępne rozpoznania, „Karto-Teka Gdańska” (2020) nr 1, s. 116-130.

Hegel G., Fenomenologia ducha, tłum. A. Landmann, Warszawa 1964.

Herbich A., Sobańda A., Dziś maja dzieci, wnuki i prawnuki. W ten sposób pokonały Hitlera, https://kultura.dziennik.pl/ksiazki/artykuly/6477152,dziewczyny-ocalale-zyd-zydowka-wojna-holocaust-anna-herbich-wojna-sprawiedliwi.html (6.10.2020).

Hernas A., Tischner i Lévinas. Księdza z rabinem spór o człowieka, „Logos i Ethos” (2004) nr 2, s. 224-236.

Jawor M., W stronę egzystencjalnego oblicza filozofii, Olsztyn 2019.

Kołakowski L., Gdzie jest miejsce dzieci w filozofii liberalnej?, „Znak” (1993) nr 10, s. 11-21.

Kołakowski L., Mentzel Z., Czas ciekawy. Czas niespokojny, Kraków 2007.

Kołakowski L., Mini wykłady o maksi sprawach, t. 1, Kraków 1997.

Kołakowski L., Moje słuszne poglądy na wszystko, Kraków 2000.

Kołakowski L., O tożsamości zbiorowej, w: Tożsamość w czasach zmiany, red. K. Michalski, Kraków 1995, s. 44-55.

Kołakowski L., Prawda i wolność, co pierwsze?, „Znak” (1994) nr 3, s. 69-73.

Kołakowski L., Jeśli Boga nie ma... O Bogu, Diable, Grzechu i innych zmartwieniach tak zwanej filozofii religii, Kraków 1988.

Kołakowski L., Wychowanie do nienawiści, wychowanie do godności, w: L. Kołakowski, Czy diabeł może być zbawiony i 27 innych kazań, Londyn 1984, s. 140-145.

Konstańczak S., Józefa Tischnera krytyka marksizmu, w: S. Konstańczak, Polska XIX i XX wieku w filozoficznym zwierciadle, Kraków 2017, s. 293-316.

Krąpiec M. A., Ja-człowiek, Lublin 1974.

Kwapiszewski J., Filozofia ks. Józefa Tischnera jako źródło dialogu, Słupsk 1998.

Lebiedziński W., Socjalizm w krzywym zwierciadle Józefa Tischnera, Warszawa 1985.

Lebiedziński W., Tischnerowska metoda krytyki socjalizmu, Warszawa 1987.

Lévinas E., Całość i nieskończoność. Esej o zewnętrzności, tłum. M. Kowalska, Warszawa 1998.

Lévinas E., Inaczej niż być lub ponad istota, tłum. P. Mrówczyński, Warszawa 2000.

Locke J., An Essay Concerning Human Understanding, Oxford 2008. 
Pico della Mirandola G., Mowa o godności człowieka, tłum. Z. Nerczuk i M. Olszewski, Warszawa 2010.

Pytając o człowieka - myśl filozoficzna Józefa Tischnera, red. W. Zuziak, Kraków 2002.

Ruszar J. M., Wokót „Polskiego kształtu dialogu”. Polskie filozofowanie (artykuł ukazał się jako wkładka w:), „Rzeczpospolita” 16.02.2002, dodatek Plus Minus nr 7, s. D4. Sartre J.-P., Byt i nicość, tłum. J. Kiełbasa i in., Kraków 2007.

Scheler M., Materialne a priori w etyce, tłum. A. Węgrzecki, „Znak” (1967) nr 12, s. $1512-1543$.

Tarnowski K., Tomizm a obecność filozofii, „Znak” (1978) nr 2, s. 198-212.

Taylor Ch., Source of Self. The Making of the Modern Identity, Cambridge 1989.

Tischner J., Czym jest „ja” transcendentalne?, w: Szkice filozoficzne Romanowi Ingardenowi $w$ darze, Kraków-Warszawa 1964, s. 349-364.

Tischner J., Filozofia dramatu, Paryż 1990.

Tischner J., Impresje aksjologiczne, „Znak” (1970) nr 2-3, s. 204-219.

Tischner J., Ja transcendentalne w filozofii Edmunda Husserla, „Studia Theologica Varsoviensia" (1964) nr 1-2, s. 349-364.

Tischner J., Michnik A., Żakowski J., Między Panem a Plebanem, Kraków 1998.

Tischner J., Myślenie wedtug wartości, Kraków 1982.

Tischner J., Spowiedź rewolucjonisty, Kraków 1993.

Tischner J., Spór o istnienie człowieka, Kraków 1998.

Tischner J., Sprawa osoby - wstępne przybliżenie, „Logos i Ethos” (1992) nr 2, s. 5-19.

Tischner J., Świat ludzkiej nadziei, Kraków 1994.

Tischner J., Zańko D., Gowin J., Przekonać Pana Boga, Kraków 1999.

Tischner J., Zło metafizyczne, czyli wejrzenie w otchłań, „Znak” (1993) nr 3, s. 13-28.

\section{Abstrakt}

\section{O możliwym, lecz nie zaistniałym sporze - problem ludzkiej wolności w ujęciu Józefa Tischnera i Leszka Kołakowskiego}

W latach 70. między Józefem Tischnerem a tomistami toczyła się bardzo ciekawa debata. Na początku lat 80 . wszedł on w spór z marksizmem. Zdaniem autora artykułu w końcówce lat 90. wiele zapowiadało, że kolejną intelektualną wojnę stoczy on z liberalizmem, a w szczególności z jego sposobem rozumienia ludzkiej wolności. Z wielu 
powodów do tego sporu nie doszło. Autor artykułu uważa, że głównym adwersarzem w tym sporze mógłby być Leszek Kołakowski.

Prawie wszyscy współcześni intelektualiści uważają, że wolność jest czymś fundamentalnym dla ludzkiego istnienia. Pogląd ten podzielali i Leszek Kołakowski, i Józef Tischner. Dlatego też spór ten dotyczyłby natury wolności wewnętrznej, a nie zewnętrznej. Każdy $\mathrm{z}$ adwersarzy inaczej rozumiał to, czym ona jest. Kołakowskiemu bliskie było liberalne ujęcie wolności. Z kolei Tischnerowskie rozumienie wolności dryfowało ku sposobowi, w jaki rozumiał je Augustyn. W tym tekście autor przybliża oba te rozumienia wolności. Uważa też, że próba zmierzenia siły argumentów obu adwersarzy mogłaby się dokonać w odniesieniu do istoty człowieka.

\section{Słowa kluczowe}

wolność, człowiek, rdzeń osobowości, świadomość, agatologiczna przestrzeń świadomości, dobro-czyńca, zło-czyńca 